\section{Austrian science minister attacks science journalists in fraud case}

The Austrian Minister for science and research, Dr Hertha Firnberg, released a 32-page document last Wednesday (16 November) attacking the science journalists of Austrian and other newspapers for poor judgment, and for unwittingly assisting in the execution of a crime. The attack, whether justified or not, threatens to disrupt the relationship-already fragile-between Austrian journalists, the ministry and the scientific community.

The government statement singled out two journalists for particularly harsh treatment: Dr Eleonore ThunHohenstein of the conservative daily Wochenpresse and Paul Uccusic of the middle-of-the-road Kurier. Their error? Publicising the work of a littleknown freelance microbiologist, Herbert Schaden, and his assistant Hertha Celta. Schaden and Celta claimed that they had developed, or would soon develop, a strain of microbe which would digest plastic. No such strain emerged after four years" work.

Schaden was detained in Austria on 11 January, and has been in jail since, awaiting trial on charges of fraudulently obtaining funds for research (amounting to some $£ \frac{t}{3}$ million) from a Dutch packaging firm and other sources. Celta was imprisoned with him but relcased on hail after two months--to feed Schaden's microbes. The microbes and Celta languish yet in Schaden's private laboratory at 99 Panzingerstrasse, a fashionable turn-ofthe-century Vicnnese villa.

Dr Firnberg's document implies that Schaden is a crook - albeit a very clever one-and attacks the journalists for helping him along the path to fraud. Some 750 articles describing Schaden's work appeared in the press between 1 February 1973 and 5 June 1974, the document states, mostly in Austria, but also in Holland and in Italy.

Schaden first came to the journalists' attention on 1 February 1973, when he sent a thick bunch of documents to the Austrian Bundersministerium für Wissenschaft und Forschung, with copies to the Austrian newspapers. The documents gave credentials, references, and evidence that Schaden and Celta had found the plastic-digesting bug. Years before, a stack of plastic containers had been found riddled with microscopic holes; Schaden had deduced the presence of bacterial action and set about isolating the active agents.

On 21 February 1973 ThunHohenstein's first article, a positive one, appeared in Wochenpresse. A Dutch journalist noticed the story and relayed it to her paper, the Haarlams Dagblad, a small but important provincial Dutch paper.

Oscar van Leer, a Dutch packaging magnate, came to hear of the story and was interested. Uccisic published his version of Schaden's work, also positive, in Kurier on 4 March. By 30 May Thun-Hohenstein had heard both that the Austrian ministry had dismissed Schaden ambiguously with a "don't ring us, we'll ring you", and that van Leer's firm (Royal Packaging Industries van Leer B. V.) was investing in Schaden's bugs. van Leer had sent a team of plastics experts-but not microbiologists-to interview Schaden and concluded he was genuine. Thun published a sarcastic article ridiculing the ministry's delay and poor judgment. On 9 June Uccisic, not a man to mince words, weighed in with his own criticism. He printed a story related by Thun: that the chief civil servant responsible for advising on the allocation of research funds in AustriaDr Wilhelm Grimburg-had threatened Thun with a court action for saying the ministry's rejection of Schaden took five lines rather than the five and a half. Uccusic made great play of that. Later a letter from Grimburg was printed in Kurier rebutting Uccusic's accusations; but Uccusic tacked a stinging comment on the end.

Grimburg's relationship with ThunHohenstein and Uccusic was therefore very sour; the more so because the ministry's popularity with scientists was at a low ebb. Austria was-and is still --enjoying its first period of socialist government for a long while, and the ministry had embarked on a "demo-

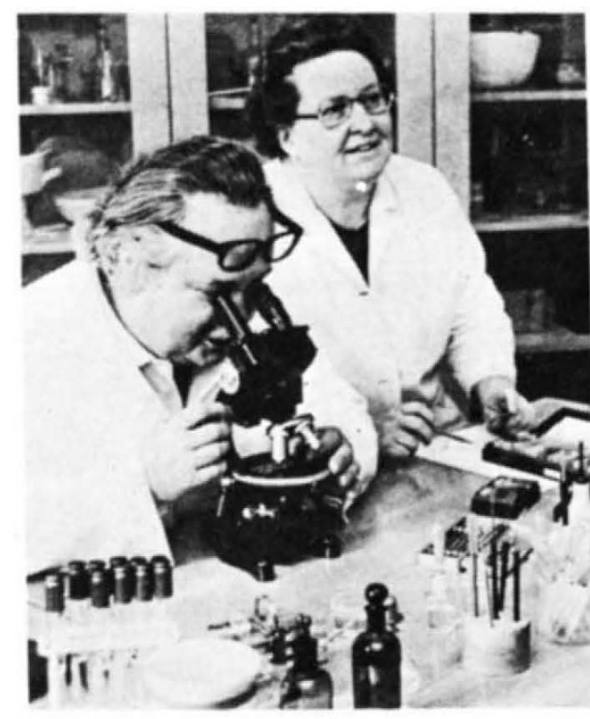

Herbert Schaden and Hertha Celta, accused of obtaining $£^{\frac{1}{3}}$ million by false pretences cratisation" of the universities (for which it is responsible), introducing students and junior professors on to decision-making bodies, and dismantling the previous patriarchal and authoritarian structures. Criticisms of competence were particularly unwelcome at that time.

But now has come the retribution. van Leer invested a large sum in Schaden, only to find his work and his claim valueless. van Leer's lawyers believe they have discovered that some 40 pages of Schaden's original documentation are careful re-writes of earlier German papers, changing names and places. So the ministry appears to be vindicated (though Schaden and Celta's case has yet to come to court, and some feel that due process of law has been disturbed by the ministry's attack). Dr Firnberg, the minister, threatens wide distribution of the report, to all politicians and universities in Austria, an act which will undoubtedly severely weaken the position of the science journalists within their own newspapers and in Austria itself.

What of the journalists? Dr ThunHohenstein dismisses the Firnberg attack and indeed still believes in Schaden; Herr Uccusic thinks Schaden "not the person we took him for". He feels however that "neither I nor Dr Thun-Hohenstein nor anyone has any proof" that Schaden is wrong. And many journalists are saying that as it has taken experts since 11 January this year to develop a watertight case against Schaden-and may take longer --how can they have been expected to judge? The development was potentially of great public interest so had the public not the right to know?

Uccusic also takes a more philosophical view. "Error is always possible" he says; "even politicians and scientists can make crrors". Uccusic believes scientific officialdom to be too hidebound-which it somtimes is-and he takes an interest in fringe science. But the belief can lead one into dangerous territory. Uccusic recognises the danger but adds "We should be open-minded and ready for new developments. In this special case no law of science forbids the development of organisms that might digest plastic. And Schaden was employing a recognised technique: to isolate a useful strain and strengthen it by multiplication and selection".

The final criticism must be laid at the door of the ministry itself. The ministry accuses the journalists of superficiality and lack of thoroughness. But the document they have produced in their haste to attack the journalists suffers from the same fault. It is too polemical; and its puts only one side of a difficult case.

Robert Walgate 